\title{
E-PARTYCYPACJA: ZASTOSOWANIA SONDAŻU INTERNETOWEGO JAKO NARZĘDZIA PARTYCYPACYJNEGO
}

\section{WSTĘP - KORZENIE PARTYCYPACJI}

Jako antidotum na spadek udziału obywateli w życiu politycznym i publicznym $\mathrm{w}$ wielu krajach podejmowane są próby angażowania obywateli do uczestnictwa w procesie tworzenia polityki i zarządzania publicznego ${ }^{1}$. Partycypacja obywateli w podejmowaniu decyzji przez władze publiczne ma rosnące znaczenie od końca drugiej połowy XX w. Cztery podstawowe kategorie partycypacji to: aktywność publiczna obywateli, angażowanie obywateli do podejmowania decyzji przez władze publiczne, partycypacja wyborcza, partycypacja obowiązkowa ${ }^{2}$. Tradycyjnie w literaturze na temat partycypacji wskazuje się różne poziomy „intensywności” - zaangażowania uczestników, które wywodza się z klasycznej koncepcji „drabiny partycypacyjnej” Arnstein: poczynając od informowania obywateli - najsłabszej formy, przez konsultowanie, włączanie w podejmowanie decyzji, współpracę, upodmiotowienie - najsilniejszej formy ${ }^{3}$.

Wskazuje się szereg funkcji partycypacji: a) przynosi ona lepszą legitymizację decyzji; b) pomaga w emancypacji wykluczonych grup społecznych; c) poprawia jakość podejmowanych decyzji; d) poprawia działanie administra$\mathrm{cji}^{4}$. W wielu krajach partycypacja jest uregulowana prawnie ${ }^{5}$. W Polsce w ciagu ostatnich kilkunastu lat obserwuje się rosnąca popularność partycypacji. W pewnym zakresie można wiazać to $\mathrm{z}$ przystapieniem do UE i wymogami związanymi z wydatkowaniem środków unijnych.

${ }^{1}$ L. Komito, e-Participation and Governance: Widening the Net, „The Electronic Journal of e-Government" 3, 2005, nr 1, s. 39-48.

${ }^{2}$ T. Kaźmierczak, Partycypacja publiczna: pojęcie, ramy teoretyczne, w: A. Olech (red.), Partycypacja publiczna: o uczestnictwie obywateli w życiu wspólnoty lokalnej, Warszawa 2011, s. 83-99.

${ }^{3}$ S. R. Arnstein, A Ladder of Citizen Participation, „Journal of the American Institute of Planners" 35, 1969, nr 4.

${ }^{4}$ P. Matczak, Formy partycypacji $w$ procesie politycznym $w$ zakresie ochrony środowiska, w: A. Olech (red.), op. cit., s. 130-155.

${ }^{5}$ W Polsce wskazać można przykładowo ustawę z 3 października 2008 r. o udostępnianiu informacji o środowisku i jego ochronie, udziale społeczeństwa w ochronie środowiska oraz o ocenach oddziaływania na środowisko. Przegląd regulacji dotyczących konsultacji społecznych w samorządzie przedstawia M. Banat w artykule: Konsultacje spoteczne w samorzqdzie terytorialnym, „Samorząd Terytorialny” 2014, nr 1-2, s. 13-25. 
Użyteczność partycypacji bywa traktowana sceptycznie ${ }^{6}$. Partycypacja jest kosztowna, uzyskiwane zaś wyniki nie zawsze sa pożyteczne (z różnych względów, także ze względu na kontestowanie jej wyników) ${ }^{7}$. Pomimo tych trudności można zaobserwować jednak duże zainteresowanie narzędziami partycypacyjnymi, tworzenie i stosowanie nowych metod i technik angażujących obywateli w życie publiczne. Szczególne znaczenie przypisywane jest technologiom informatycznym. Ich rozwój w ciagu ostatnich 25 lat zmienił kontekst i praktykę partycypacji. Pojawiło się pojęcie „e-partycypacji”. W niniejszym artykule przedstawiono funkcje e-partycypacji, stosowane narzędzia, a także krytykę zgłaszaną pod adresem tego sposobu angażowania obywateli. Następnie naszkicowano sytuację e-partycypacji w Polsce oraz szczegółowy przypadek sondażu internetowego w Poznaniu, który wykorzystywany jest jako narzędzie konsultacyjne. Na koniec przedstawiono wnioski wynikające z zastosowania sondażu internetowego jako narzędzia e-partycypacji.

\section{TECHNOLOGIE INFORMATYCZNE A PARTYCYPACJA}

Zmiany sposobów uczestnictwa obywateli w życiu publicznym po części można przypisać przemianom technologicznym i rozwojowi technik masowego komunikowania (prasa, radio, telewizja, nowe technologie informatyczne) ${ }^{8}$. Szczególne znaczenie mają nowe technologie informatyczne (ang. ICT - Information and Communication Technologies) i rozwój Internetu. Początkowo Internet oznaczał głównie digitalizację procesów konsultacyjnych, tzn. zamiast wysyłania komunikacji listowej używana była poczta elektroniczna, a dokumenty udostępniano na stronie internetowej - zamiast w postaci papierowej ${ }^{9}$. $\mathrm{Z}$ czasem doszło jednak do jakościowych zmian i wykorzystanie technologii informacyjnych oraz komunikacyjnych do angażowania społeczeństwa w procesy demokratyczne przybrało formę nazwaną e-partycypacją (elektroniczna partycypacja, e-uczestnictwem). E-partycypacja odnosi się do działania administracji publicznej, dostarczania usług publicznych, podejmowania decyzji oraz przygotowywania i wdrażania polityki publicznej. Ma ona postać interakcji między sferą społeczeństwa obywatelskiego a formalna sfera polityki $\mathrm{i}$ administracji, technologie informatyczne zaś pośredniczą w tej interakcji ${ }^{10}$. Rolą e-partycypacji jest umożliwienie obywatelom udziału w procesach podej-

${ }^{6}$ K. Friske, Polowanie na jednorożca: demokratyczna administracja publiczna?, „Samorząd Terytorialny" 2014, nr 1-2, s. 5-12.

${ }^{7}$ Zastrzeżenia bardziej filozoficznej natury zgłaszają K. Frieske i K. Pawłowska w artykule: Obywatelska partycypacja: migotanie idei, w: A. Olech (red.), op. cit., s. 61-79.

${ }^{8}$ A. Peisert, K. Stachura, Partycypacja jako wynik rozwoju technik komunikowania i zmian charakteru sfery publicznej, w: A. Olech (red.), op. cit., s. 45-60.

${ }_{9}^{9}$ M. Conroy, J. Evans-Cowley, E-participation in Planning: An Analysis of Cities Adopting On-line Citizen Participation Tools, „Environment and Planning C: Government and Policy” 24, 2006, nr 3, s. 371-384.

${ }^{10}$ C. Sanford, Characterizing e-Participation, „International Journal of Information Management" 2007, s. 406-421. 
mowania oddolnych, świadomych decyzji i podejmowania odpowiedzialności za decyzje w sprawach publicznych za pomocą narzędzi informatycznych.

Należy zauważyć, że partycypacja z wykorzystaniem narzędzi informatycznych szybko zyskała popularność i zaczęto w niej pokładać nadzieje na przemiany dotyczace funkcjonowania administracji oraz odnowy demokracji. Pojawiły się pojęcia „e-obywatelstwa”"11, a także idea Gov $2.0^{12}$, jako radykalnego sposobu naprawy słabości współczesnych państw.

\section{ZALETY I FUNKCJE E-PARTYCYPACJI}

Rozwój technologii internetowych stworzył nowe możliwości partycypacji (niemożliwe wcześniej). Narzędzia te dają możliwość stosunkowo taniego (z punktu widzenia administracji publicznej - organizatora partycypacji oraz z punktu widzenia uczestnika partycypacji) i szybkiego pozyskiwania informacji. E-partycypacja pozwala zmniejszyć koszty transakcyjne związane z dostarczaniem usług $^{13}$. Z tego punktu widzenia narzędzia internetowe stanowia duże ułatwienie ${ }^{14}$.

W ramach e-partycypacji można wyróżnić 3 zasadnicze procesy: a) pozyskiwanie informacji; b) formowanie opinii; c) podejmowanie decyzji. Mogą one zachodzić w szeregu obszarów, gdzie ma zastosowanie e-partycypacja. Zissis, Lekkas i Papadopoulou wskazują następujące obszary:

a) dostarczanie informacji (strukturyzacja i zarządzanie informacjami);

b) budowa środowisk wspólnotowych (wspierania osób wspólnie tworzących społeczności, rozwijanie wspólnych programów oraz kształtowanie i wzmacnianie społeczności);

c) konsultowanie (umożliwienie zainteresowanym stronom przekazania opinii, prywatnie lub publicznie, dotyczacych konkretnych spraw);

d) realizacja kampanii (społecznych - zgłaszanie protestów, lobbing, petycje i inne formy działania zbiorowego, z wyjątkiem kampanii politycznych);

e) realizacja kampanii politycznych (wyborczych - wspieranie polityków, partii politycznych i lobbystów w kontekście wyborów);

f) deliberacja (wspieranie wirtualnych grup dyskusyjnych, wspierających refleksję i pomagające w rozpatrywaniu spraw publicznych);

g) dyskusja/dyskurs (analiza i wspieranie dyskusji - dyskursów);

${ }^{11}$ R. K. Palat, L. Pratchett, E-citizenship: Reconstructing the Public Online, w: C. Durose, S. Greasley, L. Richardson (red.), Changing Local Governance, Changing Citizens, Bristol 2009, s. 193-209.

${ }^{12}$ S. Borins, Strategic Planning form Robert McNamara to Gov 2.0, „Public Administration Review" 70, 2010, nr 1; W. D. Eggers, Government 2.0: Using Technology to Improve Education, Cut Red Tape, Reduce Gridlock and Enhance Democracy, Plymouth 2005; D. Tapscott, A. D. Williams, D. Herman, Government 2.0: Transforming Government and Governance for the TwentyFirst Century, „New Paradigm” 2008, s. 1-25.

${ }^{13}$ L. Pratchett, S. Leach, A New Vision for Local Government: Rhetoric or Reality, „Parliamentary Affairs" 58, 2005, nr 2, s. 318-34.

${ }^{14}$ L. K. Polat, L. Pratchett, op. cit. 
h) mediacja (pomoc w mediacji lub rozstrzyganiu sporów lub konfliktów);

i) planowanie przestrzenne (wspieranie planowanie przestrzennego, środowiskowego, urbanistycznego);

j) sondaż (badanie opinii publicznej w dyskutowanych sprawach);

k) głosowanie (wybory, referenda, plebiscyty) ${ }^{15}$.

Badania pokazuja, że - przynajmniej w niektórych obszarach - e-partycypacja rzeczywiście jest wdrażana. Badania z 2004 r. dotyczące 582 amerykańskich miast powyżej 50 tys. mieszkańców pokazuja, że $35 \%$ z nich podaje adres e-mailowy do kontaktu z mieszkańcami, $55 \%$ zamieszczało w Internecie plany przestrzenne, a 37\% umieszczało protokoły ze spotkań dotyczacych planów ${ }^{16}$. W Wielkiej Brytanii program rządu zakładający, że sprawy administracji rządowej i samorządów lokalnych powinny być realizowane drogą elektroniczna, zakończył się sukcesem ${ }^{17}$.

\section{NARZĘDZIA E-PARTYCYPACJI}

W ramach e-partycypacji wykorzystywanych jest wiele narzędzi. Zissis, Lekkas i Papadopoulou dokonali ich analizy i wskazali następujące ${ }^{18}$ : webcasts $^{19}, \mathrm{FAQ}^{20}$, blogi, narzędzia do badania opinii (na bazie prób), narzędzia do badania opinii - bez procedury próbkowania, chat rooms ${ }^{21}$, gry decyzyjne, fora dyskusyjne, e-panele (grono wybranych osób, które dyskutują w pewnym okresie na dany temat), e-petycje, e-deliberatywne badanie opinii (wybrani według pewnej - zasadniczo losowej - procedury wyboru mieszkańcy maja dostarczyć pogłębionej informacji); wirtualne wspólnoty; mechanizmy alertu (drogą e-mailową oraz poprzez $\mathrm{RSS}^{22}$ ).

Trzynaście powyższych narzędzi zostało ocenionych za pomoca szeregu kryteriów (dostępność; łatwość korzystania; wymogi sprzętowe; ilość pozyskiwanej informacji; zapewnienie bezpieczeństwa i anonimowości użytkowników; interaktywność; szerokość zasięgu). Autorzy analizy wskazuja, że nie da się

${ }^{15}$ D. Zissis, D. Lekkas, A. E. Papadopoulou, op. cit., s. 195-208. Wskazać można także inne zastosowania narzędzi internetowych, choćby zakupy publiczne (e-procurment) czy e-przetargi (e-tendering), które jednak w mniejszym zakresie traktować można jako narzędzia partycypacyjne.

${ }_{16}$ M. Conroy, J. Evans-Cowley, op. cit.

17 L. K. Polat, L. Pratchett, op. cit.

${ }^{18}$ D. Zissis, D. Lekkas, A. E. Papadopoulou, op. cit.

19 Termin używany do określenia produkcji, transmisji i dostarczania prezentacji zawierających video, dźwięk oraz tekst poprzez przeglądarkę internetowa.

${ }^{20} \mathrm{Z}$ angielskiego Frequently Asked Questions - najczęściej zadawane pytania.

${ }_{21}$ Przestrzeń w serwisie oferującym chat. Podział na chatroomy służy wyodrębnieniu grup o podobnych zainteresowaniach, przynależnościach (np. gustów muzycznych) lub skupieniu tematu dyskusji, co wyrażane jest w nazwie danego chatroomu, na przykład: jazz, disco, rock, muzyka lat'60, Elvis itd.

${ }^{22}$ Dokument RSS, często zwany „kanałem”, zazwyczaj zawiera streszczoną formę wiadomości ze skojarzonej strony WWW lub jej pełny tekst. RSS umożliwia użytkownikom automatyczne śledzenie nowych treści ulubionych serwisów sieciowych. 
stworzyć jednoznacznego rankingu narzędzi, gdyż korzyści z ich zastosowania zależą od potrzeb oraz od okoliczności.

Niezależnie od zalet i wad poszczególnych narzędzi na świecie wyspecjalizowane firmy stworzyły szereg narzędzi internetowych przeznaczonych do konsultacji społecznych. Przykłady z USA, Australii, Kandy czy wielkiej Brytanii pokazuja, że kształt narzędzia do organizowania działań partycypacyjnych w sieci zależy jedynie od potrzeb zamawiającego oraz środków, które może on na dany projekt przeznaczyć. Część platform to proste narzędzia nastawione głównie na wymianę informacji, generowanie pomysłów i ich komentowanie. Inne działają na zasadzie symulatorów i oprócz tego, że zbierają informacje, pokazują także uczestnikom procesu, jakie konsekwencje pociagają za soba proponowane przez nich decyzje. Istnieją też bardzo wyrafinowane i zaawansowane platformy, które na drabinie partycypacji można by umiejscowić między poziomami współpracy a upodmiotowienia. Wiele z tych narzędzi oferuje niezwykle atrakcyjna szatę graficzną i wabi użytkowników nieszablonową formą angażowania, która nie sprowadza się jedynie do standardowego komentowania (tab. 1).

Tabela 1

Przykładowe narzędzia internetowe służące do procesów partycypacyjnych

\begin{tabular}{|c|c|c|c|}
\hline Lp. & Nazwa/kraj & Cena & Komentarz \\
\hline 1. & MindMixer/ USA & $\begin{array}{l}10-20 \text { tys. } \\
\text { dolarów } \\
\text { za projekt }\end{array}$ & $\begin{array}{l}\text { Celem tego narzędzia jest poprawienie efektywno- } \\
\text { ści i wydajności partycypacji publicznej w porówna- } \\
\text { niu z narzędziami „tradycyjnymi”. Platforma umoż- } \\
\text { liwia uczestnikom dzielenie się ideami na temat } \\
\text { polityki miasta i tematów związanych z jego rozwo- } \\
\text { jem, komentowanie pomysłów innych uczestników } \\
\text { i umiejscawianie najbardziej popularnych tematów } \\
\text { na szczycie listy. Mind Mixer stara się podnieść } \\
\text { jakość partycypacji ale także zachęca uczestników } \\
\text { do działania, stosując bardzo atrakcyjną oprawę } \\
\text { graficzna oraz elementy teorii gier, aby wszelkie } \\
\text { doświadczenia z narzędziem były satysfakcjonuja- } \\
\text { ce i angażujące. Narzędzia sa zorientowane projek- } \\
\text { towo, czyli posiadają określony początek i koniec, } \\
\text { składaja się z powiązanych ze soba elementów i sa } \\
\text { nastawione na osiagnięcie celu. Adres: www.min- } \\
\text { dmixer.com/ }\end{array}$ \\
\hline 2. & $\begin{array}{l}\text { EngagingPlans/ } \\
\text { USA }\end{array}$ & $\begin{array}{l}\text { od } 75 \text { dola- } \\
\text { rów miesięcz- } \\
\text { nie }\end{array}$ & $\begin{array}{l}\text { Użytkownicy tej platformy moga udostępniać projek- } \\
\text { ty albo projekty polityki publicznej interesariuszom, } \\
\text { a także gromadzić informacje zwrotna. Portal jest } \\
\text { wyposażony w wiele funkcji, za pomocą których użyt- } \\
\text { kownicy moga dostosować końcowy produkt do swo- } \\
\text { ich potrzeb: ankiety, kalendarz wydarzeń, bibliotekę } \\
\text { dokumentów, przyciski „lubię” oraz „udostępniam”, } \\
\text { aby móc rozpowszechniać informacje także za pomoca } \\
\text { mediów społecznościowych. Adres: http://urbaninte- } \\
\text { ractivestudio.com/ }\end{array}$ \\
\hline
\end{tabular}




\begin{tabular}{|c|c|c|c|}
\hline Lp. & Nazwa/kraj & Cena & Komentarz \\
\hline 3. & $\begin{array}{l}\text { CitizenSpace/ UK, } \\
\text { Australia, USA }\end{array}$ & $\begin{array}{l}\text { od } 3 \text { tys. } \\
\text { dolarów } \\
\text { (w zależności } \\
\text { od aplikacji) }\end{array}$ & $\begin{array}{l}\text { Narzędzie służy do zarządzania, publikowania i archi- } \\
\text { wizowania informacji zwrotnej, posiada wyszukiwar- } \\
\text { kę tematów oraz moduł do projektowania sondaży. } \\
\text { Pozwala także analizować, raportować i eksportować } \\
\text { zgromadzone informacje do plików Excel lub SPSS. } \\
\text { Administratorzy moga edytować i zarzadzać za- } \\
\text { wartościa, a także przypisywać role użytkownikom. } \\
\text { Aplikacja może być dostosowana do potrzeb różnych } \\
\text { instytucji, ale najlepiej sprawdza sie podczas dużych } \\
\text { projektów infrastrukturalnych, np. projektów auto- } \\
\text { strad itp. Adres: www.citizenspace.com }\end{array}$ \\
\hline 4. & $\begin{array}{l}\text { Crowdbrite/ USA, } \\
\text { Canada }\end{array}$ & $\begin{array}{l}\text { od } 2,5 \text { tys. } \\
\text { dolarów } \\
\text { (w zależności } \\
\text { od aplikacji) }\end{array}$ & $\begin{array}{l}\text { Narzędzie to jest skonstruowane zgodnie z koncepcja } \\
\text { charette - warsztatu partycypacyjnego zorientowa- } \\
\text { nego na zaprojektowanie konsultowanego obszaru } \\
\text { przestrzeni publicznej (projekt lub plan zagospodaro- } \\
\text { wania przestrzennego). Użytkownicy moga za pośred- } \\
\text { nictwem portalu uczestniczyć w takich warsztatach } \\
\text { w sieci przez pisanie komentarzy oraz „przyklejanie } \\
\text { karteczek” w konkretnym miejscu na planie/projek- } \\
\text { cie. Za pośrednictwem „,karteczek” można też doda- } \\
\text { wać zdjęcia lub nagrania video, a także głosować i tym } \\
\text { samym popierać wybrane idee. Ze wszystkich funk- } \\
\text { cjonalności portalu można korzystać także za pomoca } \\
\text { urządzeń mobilnych, co dodatkowo umożliwia efek- } \\
\text { tywne wykorzystywanie narzędzia podczas spotkań } \\
\text { „w rzeczywistości”. Wprowadzane dane sa widoczne } \\
\text { w czasie rzeczywistym. Adres: www.crowdbrite.com/ }\end{array}$ \\
\hline 5. & Ideascale/ USA & $\begin{array}{l}\text { od ok. } 100 \\
\text { dolarów mie- } \\
\text { sięcznie }\end{array}$ & $\begin{array}{l}\text { Narzędzie pozwala wykorzystywać ideę crowd-sour- } \\
\text { cingu w celu zarządzania informacjami dotyczącymi } \\
\text { projektów, polityki, firm i ich moderowania. Platfor- } \\
\text { ma pomaga kompilować informacje oraz gromadzić } \\
\text { informację zwrotna od użytkowników w jednym miej- } \\
\text { scu w sieci. Użytkownicy moga publikować własne } \\
\text { pomysły, komentować, głosować oraz zgadzać lub nie } \\
\text { zgadzać się z komentarzami innych. Najpopularniej- } \\
\text { sze tematy sa umieszczane na górze strony (podobnie } \\
\text { jak w MindMixerze). Z Ideascale można korzystać za } \\
\text { pośrednictwem strony internetowej, mediów społecz- } \\
\text { nościowych czy widgetów, a także za pośrednictwem } \\
\text { urządzeń mobilnych. Adres: http://ideascale.com/ }\end{array}$ \\
\hline 6. & $\begin{array}{l}\text { PlaceSpeak/ Ca- } \\
\text { nada }\end{array}$ & $\begin{array}{l}\text { od ok. 200- } \\
300 \text { dolarów } \\
\text { rocznie }\end{array}$ & $\begin{array}{l}\text { Platforma pozwala użytkownikom publikować własne } \\
\text { pomysły i dzielić się nimi. Administratorzy natomiast } \\
\text { mogą umieszczać informacje na temat kontekstu kon- } \\
\text { sultacji. Cechą wyróżniajacca PlaceSpeak jest fakt, że } \\
\text { wymaga od użytkownika adresu zamieszkania, aby } \\
\text { program mógł połączyć jego identyfikator z lokaliza- } \\
\text { cja. Ta funkcja pozwala administratorom skupić się } \\
\text { na dialogu mieszkańców poszczególnych ważnych dla } \\
\text { procesu dzielnic i pozwala uzyskać informację zwrot- } \\
\text { ną na temat np. konsultowanej polityki od osób, któ- } \\
\text { rych terytorialnie bardziej ona dotyczy. Adres: www. } \\
\text { placespeak.com/ }\end{array}$ \\
\hline
\end{tabular}




\begin{tabular}{|c|c|c|c|}
\hline Lp. & Nazwa/kraj & Cena & Komentarz \\
\hline 7. & $\begin{array}{l}\text { MetroQuest/ Ca- } \\
\text { nada }\end{array}$ & $\begin{array}{l}\text { od ok. } 9 \text { tys. } \\
\text { dolarów za } \\
\text { projekt }\end{array}$ & $\begin{array}{l}\text { Narzędzie pomaga skonstruować mechanizm wspie- } \\
\text { rający procesy planistyczne. Pozwala skupić się in- } \\
\text { stytucji zapraszającej do konsultacji na określeniu } \\
\text { priorytetów planistycznych danej społeczności, zma- } \\
\text { powaniu kwestii dotyczacych transportu i planowania } \\
\text { miejskiego (np. zaznaczeniu na mapie miejsc, które } \\
\text { wymagaja usprawnienia), projektowaniu budżetu } \\
\text { oraz projektowaniu strategii. Adres: http://metroqu- } \\
\text { est.com/ }\end{array}$ \\
\hline 8. & $\begin{array}{l}\text { E-Deliberation/ } \\
\text { Canada }\end{array}$ & $\begin{array}{l}\text { ceny ustala- } \\
\text { ne indywidu- } \\
\text { alnie, zniżki } \\
\text { dla organiza- } \\
\text { cji pozarzą- } \\
\text { dowych } \\
\text { i grup niefor- } \\
\text { malnych }\end{array}$ & $\begin{array}{l}\text { Narzędzie to jest skonstruowane tak, by gromadzić } \\
\text { informacje, dzielić się nimi, umożliwić zaangażowa- } \\
\text { nym obywatelom faktyczny wpływ na proces decy- } \\
\text { zyjny. Użytkownicy staja się uczestnikami bardzo } \\
\text { specyficznego procesu, który opiera się na doświad- } \\
\text { czeniach zarówno akademików, jak i praktyków. } \\
\text { W rezultacie platforma prowadzi uczestników przez } \\
\text { poszczególne fazy procesu, z których każda posiada } \\
\text { inne zasady zaangażowania, materiały na temat } \\
\text { kontekstu i kryteria decyzyjne. Możliwe sa różne } \\
\text { warianty procesu w zależności od kompleksowości } \\
\text { tematu i pożądanego efektu. Adres: www.e-delibe- } \\
\text { ration.com }\end{array}$ \\
\hline 9. & $\begin{array}{l}\text { Open Town Hall/ } \\
\text { USA }\end{array}$ & $\begin{array}{l}\text { od ok. } 2,5 \\
\text { tys. dolarów } \\
\text { na rok }\end{array}$ & $\begin{array}{l}\text { Narzędzie pozwala użytkownikom głosować i popie- } \\
\text { rać konkretne idee, z których najbardziej popularne } \\
\text { są najlepiej widoczne na stronie. Użytkownicy moga } \\
\text { dodawać zdjęcia oraz nagrania video w celu uzupeł- } \\
\text { niania swoich pomysłów, a administratorzy moga } \\
\text { odpowiadać na nie publicznie bądź przez wysyłanie } \\
\text { prywatnych wiadomości. Narzędzie zorientowane } \\
\text { jest na komunikację. Adres: www.opentownhall. } \\
\text { com/ }\end{array}$ \\
\hline 10. & $\begin{array}{l}\text { Citizen Par- } \\
\text { ticipation Suite by } \\
\text { Granicus/ USA }\end{array}$ & $\begin{array}{l}\text { od ok. } 300 \\
\text { dolarów mie- } \\
\text { sięcznie }\end{array}$ & $\begin{array}{l}\text { Narzędzie jest zbudowane z dwóch programów: Ci- } \\
\text { vicIdeas and eComment. Pierwszy to program po- } \\
\text { zwalający generować idee i dzielić się nim członkom } \\
\text { społeczności, promować je poprzez Facebooka czy pro- } \\
\text { wadzić ich ranking. Drugi jest zintegrowany z agen- } \\
\text { dami różnych spotkań, np. samorządu terytorialnego, } \\
\text { i umożliwia użytkownikom pozostawienie wiadomości } \\
\text { tekstowej lub video na temat poszczególnych elemen- } \\
\text { tów agendy (możliwe jest także generowanie rapor- } \\
\text { tów z opiniami). Narzędzie ma na celu zniwelowanie } \\
\text { barier w partycypacji na poziomie samorządu tery- } \\
\text { torialnego przez umoźliwienie wyrażania opinii bez } \\
\text { konieczności obecności na konkretnym spotkaniu. } \\
\text { Adres: www.granicus.com/ }\end{array}$ \\
\hline 11. & $\begin{array}{l}\text { OpenNorth/ Ca- } \\
\text { nada }\end{array}$ & $\begin{array}{l}\text { w zależności } \\
\text { od narzędzia } \\
\text { darmowe } \\
\text { lub płatne } \\
\text { od ok. } 4 \text { tys. } \\
\text { dolarów za } \\
\text { projekt }\end{array}$ & Adres: http://opennorth.ca/ \\
\hline
\end{tabular}




\begin{tabular}{|c|l|l|l|}
\hline Lp. & \multicolumn{1}{|c|}{ Nazwa/kraj } & \multicolumn{1}{c|}{ Cena } & \multicolumn{1}{c|}{ Komentarz } \\
\hline 12. & $\begin{array}{l}\text { EngagementHQ } \\
\text { from Bang the } \\
\text { Table/ Australia } \\
\text { od ok. } 700 \\
\text { dolarów mie- } \\
\text { sięcznie }\end{array}$ & $\begin{array}{l}\text { Główna osią tej platformy jest forum umożliwiają- } \\
\text { ce dzielenie się pomysłami oraz komentowanie ich, } \\
\text { a także - w wersji minimalnej - zgadzanie lub nie- } \\
\text { zgadzanie się z opiniami innych. Cała zawartość fo- } \\
\text { rum może być „tagowana” lub kategoryzowana przez } \\
\text { administratora. Dodatkowa funkcja „księga gości” po- } \\
\text { zwala także na pozostawienie komentarzy bez gene- } \\
\text { rowania dalszej dyskusji. Adres: http://bangthetable. } \\
\text { com/ }\end{array}$ \\
\hline 13. & Textizen/ USA & $\begin{array}{l}\text { cena ustala- } \\
\text { na indywidu- } \\
\text { alnie }\end{array}$ & $\begin{array}{l}\text { Narzędzie zostało skonstruowane po to, by umożliwić } \\
\text { mieszkańcom, którzy nie mają dostępu do Interne- } \\
\text { tu ani smartphone’ów, uczestnictwo w partycypacji } \\
\text { online. Program wykorzystuje SMS-y, aby umożliwić } \\
\text { mieszkańcom uczestnictwo w sondażach dotyczaccych } \\
\text { kwestii publicznych. Administratorzy natomiast } \\
\text { moga w prosty sposób dane te gromadzić i generować } \\
\text { raporty. Adres: www.textizen.com/ }\end{array}$ \\
\hline
\end{tabular}

Źródło: D. G. Rucker, Online Public Participation Platforms and Applications (Overview) 2014 oraz strony portali internetowych.

Należy zauważyć, że po pierwsze, narzędzia przedstawione w powyższej tabeli sa stosunkowo tanie. Po drugie, są one dość zróżnicowane, za względu na pełnione funkcje i możliwe do uzyskania wyniki. Wymagają one dobrania w zależności od konkretnej potrzeby.

\section{KRYTYKA E-PARTYCYPACJI}

Mimo atrakcyjności i rozwoju e-partycypacji, rozwoju narzędzi wzbudza ona zastrzeżenia. Po pierwsze, ambicje zasadniczych przemian zarządzania publicznego, jakie miały się pojawić wraz z zastosowaniem narzędzi informatycznych, okazały się zbyt wielkie. Idea Gov 2.0 wdrażana jest powoli. Meijer et al. wskazują $a^{23}$ trzy zasadnicze czynniki mające wpływ na wdrażanie idei Gov. 2.0: a) przywództwo, a w szczególności - nowe przywództwo, które oznacza odejście od tradycyjnych ról biurokratycznych; b) zachęty dla obywateli, by skorzystali z nowych narzędzi i możliwości; c) zaufanie, dzięki któremu obywatele gotowi są ujawnić swoje preferencje, opinie i tożsamość, w sposób i w zakresie, które będą dla nich komfortowe. Każdy z tych czynników okazuje się barierą we wdrażaniu Gov. 2.0.

Krytycy e-partycypacji wskazuja, że tak jak demokracja wymaga dobrze poinformowanych i aktywnych obywateli, tak i wymaga ich e-partycypacja. Dodatkowo wykorzystanie narzędzi informatycznych może tworzyć tzw. lukę

${ }^{23}$ A. J. Meijer et al., Government 2.0: Key Challenges to Its Realization, „Electronic Journal of e-Government" 10, 2012, nr 1, s. 59-69. 
cyfrowa (ang. digital gap) i prowadzić do cyfrowego wykluczenia ${ }^{24}$. Zwiąane to jest z tym, że e-partycypacja wymaga posiadania odpowiednich umiejętności oraz posiadania sprzętu. Wykorzystanie narzędzi informatycznych rodzi też zastrzeżenia związane z ochroną prywatności. Wykorzystanie narzędzi informatycznych w specyficzny sposób prowadzi do ujawniania tożsamości. Przykładowo Facebook skłania do szerokiego ujawniania prywatności. Jednocześnie istnieją możliwości anonimizacji aktywności, z których obywatele nie zawsze zdaja sobie sprawę.

Nie jest też sprawą jasna, czy narzędzie informatyczne stanowi innowacyjny mechanizm poprawiajacy jakość procesów w domenie publicznej, czy też konserwują one i wzmacniają już istniejące nierówności, układy interesów itd. ${ }^{25}$

Zastrzeżenia dotyczą także spraw bardziej szczegółowych. Polat i Pratchett $^{26}$ zwracają uwagę, że rozwój technologii informatycznych, oferujacy ułatwienia w komunikacji między władzą a obywatelami, niekoniecznie musi być związany z promocją lokalizmu. Może być wręcz przeciwnie - narzędzia informatyczne, ułatwiając nawiązywanie kontaktów w skali globalnej, moga osłabiać więzi sąsiedzkie i lokalne na rzecz sieci kontaktów oderwanych od lokalnych przestrzeni. Autorzy wskazują jednak, że w rzeczywistości takie narzędzia, jak poczta elektroniczna lub Facebook, służą także do mobilizacji lokalnej i wspierają lokalną aktywność.

E-partycypacja może prowadzić do indywidualizacji, co nie zawsze jest korzystne z punktu widzenia procesu politycznego ${ }^{27}$. Na przykład e-głosowanie eliminuje wpływ instytucji zbiorowych i pewne symboliczne wartości związane z obecnością w lokalu wyborczym, co może prowadzić do mniej refleksyjnego głosowania ${ }^{28}$.

Narzędzia informatyczne zastosowane do e-partycypacji niekoniecznie musza prowadzić do budowy wartości obywatelskich. Program informatyzacji przyjęty przez rząd brytyjski, zakładajacy, że sprawy administracji rządowej i samorządów lokalnych powinny być prowadzone drogą elektroniczna, został zrealizowany. Jednak Polat i Pratchett wskazują ${ }^{29}$, że zadowolenie, które obywatele wykazują z tego powodu, ma charakter zadowolenia konsumentów, a nie obywateli. Natomiast partycypacyjne zastosowania są mizerne. Narzę-

\footnotetext{
${ }^{24}$ W. Dutton, E. Helsper, The Internet in Britain 2007, Oxford 2007.

${ }^{25}$ K. Kraemer, K. King, Information Technology and Administrative Reform: Will e-Government be Different?, „The International Journal of Electronic Government Research” 2, 2005, nr 1, s. 1-20; T. Zarycki, Społeczne konsekwencje rozwoju Internetu - rewolucja czy reprodukcja struktur społecznych?, w: D. Batorski, M. Marody, A. Nowak (red.), Społeczna przestrzeń Internetu, Warszawa 2002, s. 337-346; D. Batorski, Internet a nierówności społeczne, „Studia Socjologiczne” 2005, nr 2 (177), s. 107-131.

${ }^{26}$ L. K. Polat, L. Pratchett, op. cit.

27 Ibidem.

${ }^{28}$ L. Pratchett, M. Wingfield, Piloting e-Voting: Lessens and Limitations from the UK Experience, w: N. Kersting, H. Boldersheim (red.), Electronic Voting and Democracy: A Comparative Analysis, Basingstoke 2004, s. 172-92.

${ }^{29}$ L. K. Polat, L. Pratchett, op. cit.
} 
dzia informatyczne używane są zwykle w ten sposób, że stosunkowo niewielkie grupy przekazują informacje stosunkowo waskim grupom interesu.

Nie wiadomo też, czy nowoczesne technologie powielają metody partycypacji wykorzystywane poza siecia, czy też wprowadzają zupełnie nowa jakość. Badania przeprowadzone przez Gibsona i Cantijoch dotyczące związku pomiędzy internetowymi a „tradycyjnymi” narzędziami partycypacji pokazały $^{30}$, że Internet pozwala zintensyfikować działania prowadzone poza siecia. Z kolei badania przeprowadzone przez Oser et al. na reprezentatywnej próbie Amerykanów w 2008 r. pokazały ${ }^{31}$, że istnieją empiryczne różnice pomiędzy partycypacją online a offline. Można wyróżnić grupę respondentów, która preferuje internetowe uczestnictwo w życiu publicznym. Jednak wbrew temu, co twierdzą niektórzy autorzy, nie rezygnuje przy tym z uczestnictwa pozainternetowego. Uzyskane rezultaty pokazały także, że aktywiści internetowi różnią się znacząco od aktywistów nieinternetowych wiekiem (sa młodsi), nie występują natomiast znaczące różnice, jeśli chodzi o płeć oraz status społeczno-ekonomiczny. Autorzy wskazuja, że wnioski z badań przeprowadzonych w USA mogą nie być przekładalne na inne kraje, a słabościa danych wykorzystanych w badaniach mógł być fakt odbywania się (w trakcie ich pozyskiwania) kampanii prezydenckiej Baracka Obamy, który podobnie jak inni kandydaci w wyborach prezydenckich, do Kongresu czy na gubernatora potrafil wykorzystać potencjał Internetu i zachęcić do poparcia różne grupy osób.

W przeciwieństwie do przykładów z USA Campante et al. dowodzą ${ }^{32}$, że szerokopasmowy Internet miał znaczaco negatywny wpływ na frekwencję w wyborach parlamentarnych we Włoszech pomiędzy 1996 a 2008 r. Jednak jest on jednocześnie pozytywnie kojarzony z innymi formami partycypacji, zarówno online, jak i offline: pojawieniem się oddolnych internetowych ruchów protestujących i frekwencji w referendach krajowych (którym znacząco sprzeciwiały się główne partie). Ponadto autorzy pokazali także, że negatywny wpływ Internetu na frekwencję w wyborach parlamentarnych uległ znaczącemu odwróceniu po 2008 r., kiedy to lokalne ruchy oddolne zjednoczyły się w Ruch Pięciu Gwiazd z własną listą wyborczą. Potwierdza to przypuszczenia, że efekty dostępności Internetu zmieniaja się w zależności od konkretnego rodzaju zaangażowania. Poza tym znaczenie ma zestaw pojawiających się na scenie politycznej aktorów, którzy mogą skorzystać z dobrodziejstw nowych technologii i tym samym trafić do rozczarowanych i zniechęconych rzesz wyborców. Nowe formy mobilizacji moga oddziaływać na proces wyborczy głównego nurtu, przekształcając strategię „wychodzę” w strategię „głosuję".

${ }^{30}$ R. Gibson, M. Cantijoch, Conceptualizing and Measuring Participation in the Age of the Internet: Is Online Political Engagement Really Different to Offline?, „The Journal of Politics” 75, 2013.

31 J. Oser et al., Is Online Participation Distinct from Offline Participation? A Latent Class Analysis of Participation Types and Their Stratification, „Political Research Quarterly” 66, 2013.

${ }^{32}$ F. Campante et al., Politics 2.0: The Multifaceted Effect of Broadband Internet on Political Participation (working paper), 2013. 


\section{E-PARTYCYPACJA W POLSCE}

W Polsce internetowe narzędzia konsultacji społecznych stosowane są na coraz szerszą skalę. Na duży potencjał tych narzędzi wskazywali niemal 10 lat temu twórcy raportu: „Obywatele współdecydują. Przewodnik po partycypacji społecznej" ${ }^{33}$. Wśród narzędzi wymieniali e-maile i listy mailingowe, grupy i fora internetowe, telefonię internetową (np. skype) i e-sondaże, a także serwisy umożliwiające składanie petycji czy przeznaczone specjalnie do konsultacji społecznych strony internetowe. Twórcy raportu opisywali zarówno szanse, jak i bariery dotyczące poszczególnych narzędzi. Zwracali także uwagę na niebezpieczeństwo przerostu formy nad treścią. Wskazują oni, że czasami lepiej skorzystać z „tradycyjnego" e-maila niż skomplikowanej strony internetowej. Te pierwsze moga posłużyć do uzyskania pojedynczych opinii na dany temat, podczas gdy te drugie są wykorzystywane w Polsce głównie do konsultowania dokumentów o dużych rozmiarach.

Fundacja Badań i Innowacji Społecznych „Stocznia” 4 lata temu utworzyła portal ${ }^{34}$, który umożliwia różnym instytucjom konsultowanie aktów prawa i innych dokumentów określających politykę publiczną. Serwis zapewnia powszechny dostęp do projektu danego dokumentu, daje możliwość określenia czasu konsultacji oraz wyrażania opinii na temat danego dokumentu. Opinie widoczne sa dla wszystkich, a po zakończeniu konsultacji instytucja zapraszająca ustosunkowuje się do poszczególnych uwag. Następnie zarówno dokument, jak i wszystkie uwagi są automatycznie przenoszone do ogólnodostępnego archiwum konsultacji. Obecnie na portalu trwaja 3 procesy konsultacyjne, a 101 zostało zakończonych (stan na 20 czerwca 2014 r.). Podobny serwis ${ }^{35}$ utworzyła Fundacja Laboratorium Badań i Działań Społecznych „SocLab”. Dotychczas za pomoca portalu przeprowadzono cztery procesy konsultacyjne wszystkie na Podlasiu. Internetowe konsultowanie dokumentów jest także często praktykowane za pomoca własnych platform, np. przez Regionalne Dyrekcje Ochrony Środowiska, które mają obowiązek konsultowania dokumentów planistycznych dotyczących obszarów chronionych ${ }^{36}$.

\section{SONDAŻ INTERNETOWY JAKO NARZĘDZIE PARTYCYPACJI}

Przedstawione powyżej rozważania pokazują że mimo wszystkich zalet narzędzia e-partycypacji wymagają doboru stosownie do potrzeb. Nie da się wskazać narzędzi, które mogłyby być uniwersalnie stosowane.

Narzędziem, które wydaje się mieć stosunkowo użyteczne zastosowania, jest sondaż internetowy. Jest to narzędzie szeroko stosowane do wielu celów,

${ }^{33}$ D. Długosz, J. J. Wygnański, Obywatele wspótdecyduja. Przewodnik po partycypacji spotecznej, Warszawa 2005.

${ }^{34}$ Zob. www.mamzdanie.org.pl.

${ }^{35}$ Zob. www.konsultacje.soclab.org.pl.

${ }^{36}$ Zob. http://pzo.gdos.gov.pl. 
w tym do badań naukowych ${ }^{37}$. Couper wyróżnia 8 typów sondaży internetowych: trzy z nich opierają się na nieprobabilistycznych metodach doboru próby, pięć pozostałych zaś opiera się na metodach probabilistycznych. Pierwsze trzy typy to:

a) sondaże jako zabawa lub rozrywka (sondaż typu: „pytanie dnia”, bez pretensji do reprezentatywności i do naukowego charakteru);

b) sondaże opierajace się na dobrowolnym uczestnictwie każdego, kto się zgłosi. Zwykle nie stosuje się kontroli dostępu i nieraz brakuje kontroli wielokrotnego dostępu do ankiety. Organizator zwykle zachęca do udziału wszystkich zainteresowanych. Różnica między tym typem a poprzednim polega na tym, że mamy tu pretensje do naukowego charakteru badania. Couper uznaje, że jest to najbardziej popularny typ sondażu internetowego;

c) sondaże opierające się na bazach danych wolontariuszy - użytkowników Internetu. Wolontariusze, rejestrując się, podają swoje podstawowe dane społeczno-demograficzne. Badanie polega na doborze wolontariuszy. W niektórych przypadkach wyniki sa też weryfikowane przez badanie telefoniczne. Wyniki sa interpretowane za pomoca modeli i ważenie. Umożliwia to pewna kontrolę, lecz w dalszym ciagu jest to sondaż oparty na respondentach, którzy się samodzielnie zgłosza.

Powyższe trzy metody opierające się na próbkowaniu nie mogą być traktowane jako badanie reprezentacyjne. W przypadku poniższych pięciu metod probabilistycznych również nie ma gwarancji reprezentatywności, głównie ze względu na kłopoty z realizacją próby, lecz bazują one na wiedzy na temat populacji oraz informacji na temat doboru próby. Pozwala to na kontrolowanie i szacowanie błędu. Są to następujące typy:

a) sondaż obejmujący pewną grupę (np. odwiedzających daną stronę internetowa), polegajacy na wysłaniu zaproszenia do wypełnienia ankiet do co $n$-tej osoby (w sposób analogiczny do exit poll);

b) sondaż bazujący na listach osób z grup korzystających z Internetu, np. studentów lub pracowników firm. Do wylosowanych osób wysyłany jest email z zaproszeniem do wzięcia udziału w badaniu;

c) sondaż, w którym droga internetowa stanowi jedną z możliwości (obok np. papierowej ankiety). Jest to sposób stosowany w firmach i organizacjach;

d) sondaż opierający się na dobranych użytkowników Internetu. Użytkownicy są wcześniej dobierani (metodą probabilistyczna) i rekrutacja odbywa się poprzez kontakt telefoniczny;

e) sondaż bazujący na próbie reprezentatywnej całej populacji. Dobrane osoby muszą być wyposażone w sprzęt, jeśli go nie posiadaja. Tak robia np. firmy badające rynek telewizyjny.

Każda z metod opierających się na próbkowaniu probabilistycznym pozwala na ocenę błędów - przynajmniej ich oszacowanie. Choć generalnie wykorzystywanie narzędzi internetowych pozwala obniżyć koszty badań, metody bardziej rzetelne są droższe. W każdym przypadku wybór metody jest pochodna potrzeb oraz ograniczeń budżetowych.

${ }^{37}$ M. P. Couper, Web Surveys: A Review of Issues and Approaches, „The Public Opinion Quarterly" 64, 2000, nr 4, s. 464-494. 


\section{SONDAŻE INTERNETOWE W POZNANIU}

W Poznaniu sondaż internetowy jest stosowany od kilku lat, głównie przy okazji konsultacji. Niektóre z procesów konsultacyjnych są zakrojone na dość szeroką skalę, np. Poznański Budżet Obywatelski. W tabeli 2 przedstawiono przegląd konsultacji społecznych przeprowadzonych za pomocą narzędzi internetowych, z których zdecydowana większość opierała się na wykorzystaniu ankiety/sondażu internetowego.

Zastosowanie sondażu internetowego w Poznaniu można uznać za udane w tym sensie, że wielu przypadkach odzew był duży. Należy jednak zwrócić uwagę na dużą rozpiętość zainteresowania: od prawie 50 tys. oddanych głosów w przypadku głosowania w ramach Poznańskiego Budżetu Obywatelskiego do 10 głosów - w przypadku opinii nt. Planu Transportowego Aglomeracji Poznańskiej. Można wskazać na kilka czynników, które mają znaczenie dla skali zainteresowania: a) charakter sprawy (od spraw prostych do kompleksowych zagadnień); b) typ głosowania (od prostego głosowania referendalnego, typu tak/nie, do zgłaszania złożonych opinii); c) nagłośnienie w mediach (od spraw, które nie budzą zainteresowania mediów, do „gorących tematów", zwłaszcza w otoczce skandalu); d) zdolność aktywistów do mobilizowania zainteresowania mieszkańców.

Ważnym aspektem sondażu jest przejrzystość, prostota i ograniczona długość kwestionariusza, tak aby każdy mieszkaniec mógł go wypełnić i nie musiał na to poświęcać zbyt wiele czasu. Nie można jednak mówić o prostej zależności, że im prostszy kwestionariusz, tym więcej opinii. Doświadczenia poznańskiego Urzędu Miasta pokazują, że nawet dłuższe kwestionariusze mogą spotkać się z zainteresowaniem mieszkańców. Tak było np. w przypadku konsultacji dotyczących zagospodarowania terenów wokół obszaru Golęcina. Trzeba jednak zauważyć, że ten przypadek jest szczególny, ponieważ dotyczy terenu, który jest postrzegany jako ważny dla lokalnej społeczności, a dodatkowo zwiazzanych jest z nim kilku bardzo czynnych grup aktywistów, którzy stymulowali proces udziału w konsultacjach. Podobnie było w przypadku Poznańskiego Budżetu Obywatelskiemu, gdy każdemu finaliście zależało na pozyskiwaniu głosów, czy konsultacji dotyczących tematów „rowerowych".

Niewątpliwie prostota i zwięzłość kwestionariusza internetowego, choć może być pewnym ograniczeniem, jest jednak zalecana, i to szczególnie w przypadku tematów budzących nieco mniejsze zainteresowanie społeczne. Jako potwierdzenie tej tezy może posłużyć przykład funkcjonującego w Poznaniu forum internetowego, które jest poświęcone właśnie konsultacjom społecznym. Jest jednak ono praktycznie nieużywane. Rozpoznanie przeprowadzone przez Urząd pokazuje, że dostęp do forum jest uznawany za trudny i wielostopniowy (rejestracja, logowanie), tematy są mało atrakcyjne, brakuje stałej obecności moderatora z instytucji zapraszającej do konsultacji, który reagowałby na komentarze. Poza tym portale społecznościowe dają większe możliwości, ponieważ w jednym miejscu są zdolne łączyć funkcje wielu forów, a reakcja może być natychmiastowa. 


\begin{tabular}{|c|c|c|c|c|}
\hline \multirow{7}{*}{ 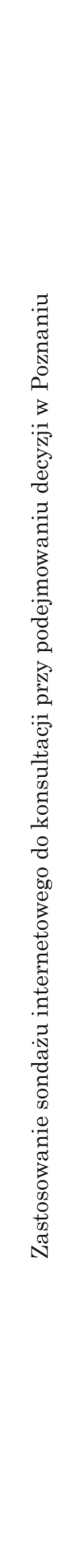 } & 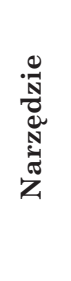 & 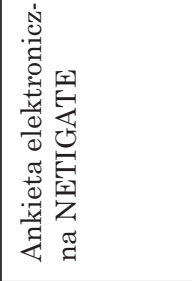 & 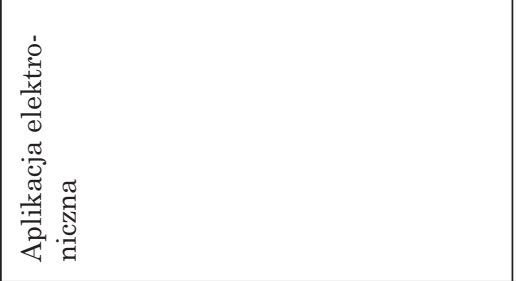 & 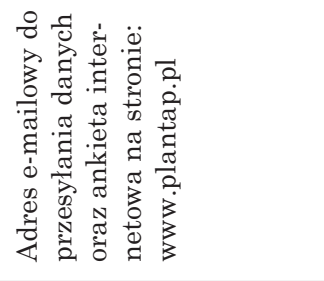 \\
\hline & 苞 & 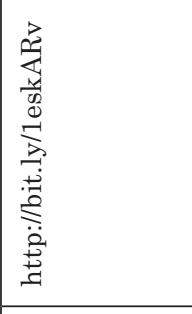 & 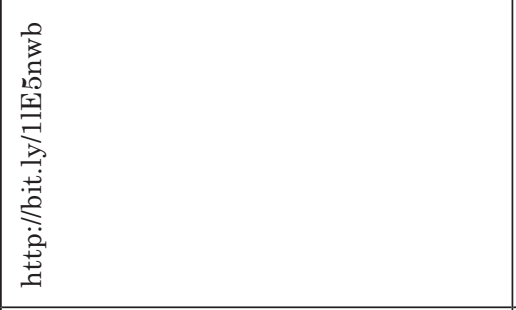 & 要 \\
\hline & 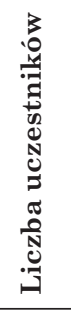 & $\underset{\infty}{\stackrel{5}{+}}$ & 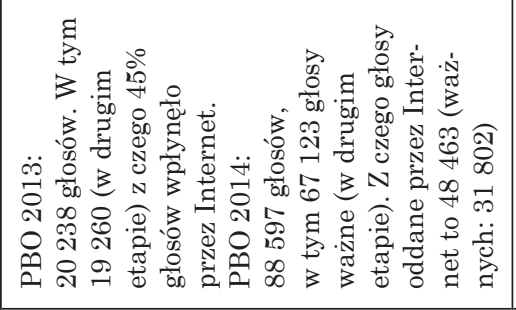 & 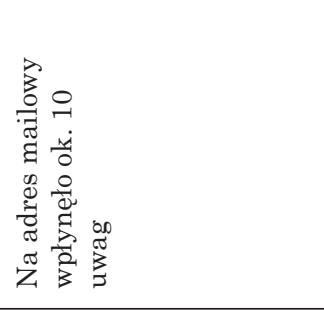 \\
\hline & 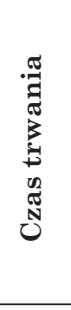 & 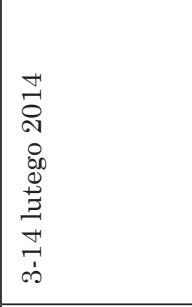 & 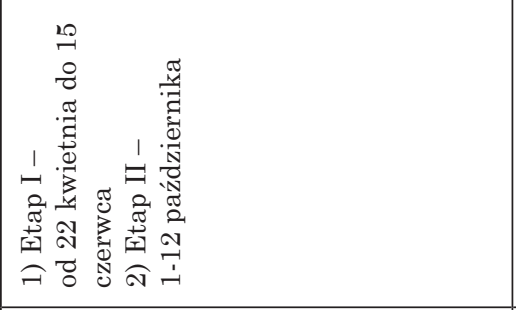 & 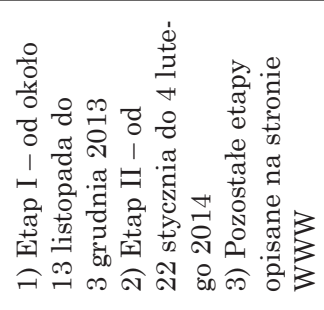 \\
\hline & 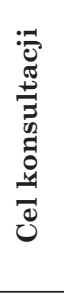 & 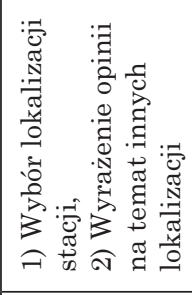 & 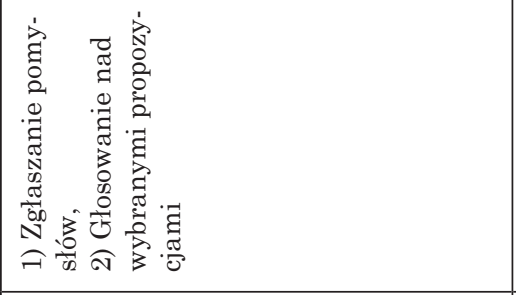 & 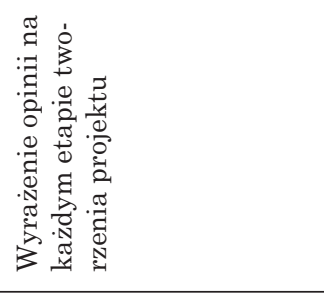 \\
\hline & 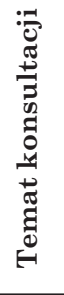 & 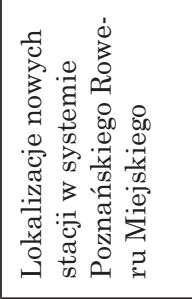 & 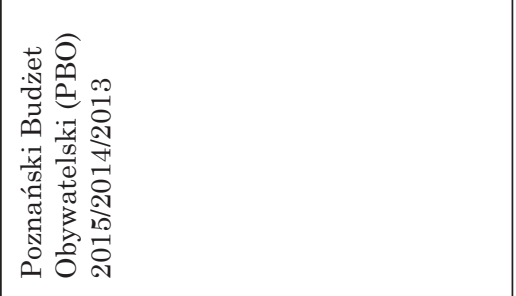 & 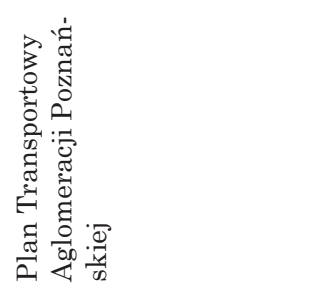 \\
\hline & $\dot{\grave{a}}$ & $\dot{-}$ & oi & $\infty$ \\
\hline
\end{tabular}




\begin{tabular}{|c|c|c|c|c|}
\hline 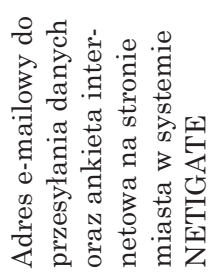 & 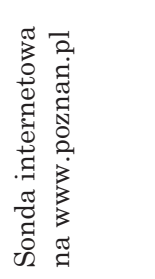 & & 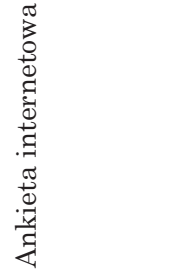 & 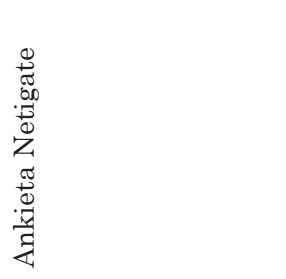 \\
\hline 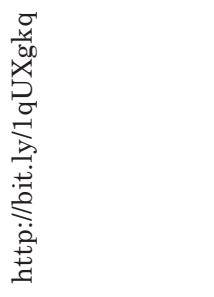 & 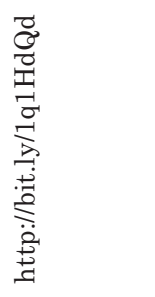 & 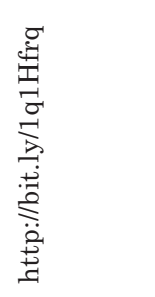 & 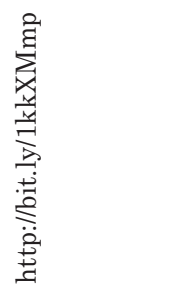 & 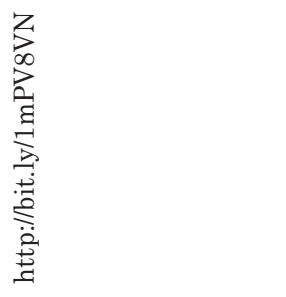 \\
\hline$\underset{7}{\not}$ & $\begin{array}{l}\searrow \\
\varnothing \\
\infty \\
\text { 싱 }\end{array}$ & $\begin{array}{l}0 \\
i \frac{1}{0} \\
\text { شi }\end{array}$ & $\begin{array}{l}\stackrel{8}{\circ} \\
\text { iㅕㅇ }\end{array}$ & 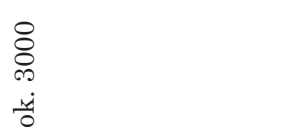 \\
\hline 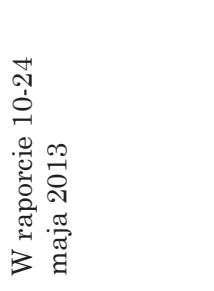 & 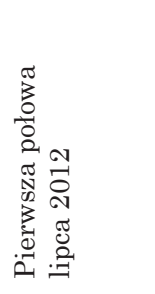 & 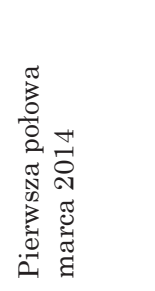 & 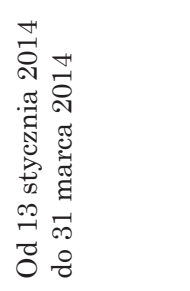 & 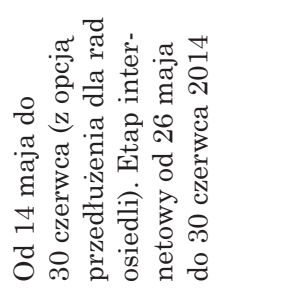 \\
\hline 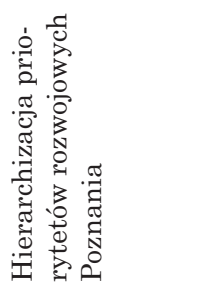 & 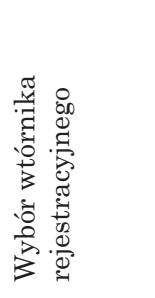 & 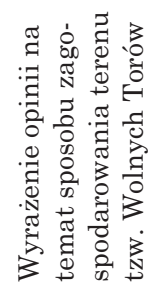 & 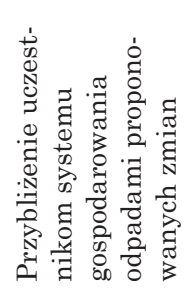 & 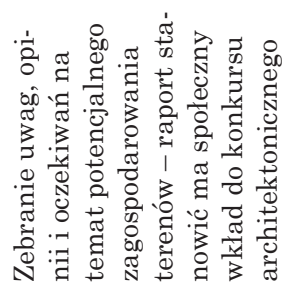 \\
\hline 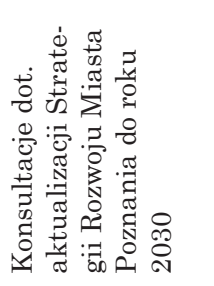 & 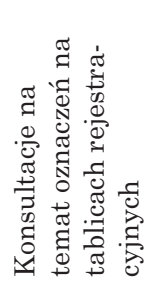 & 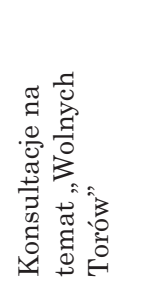 & 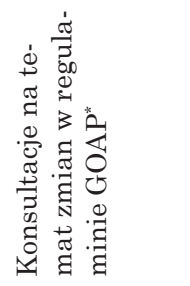 & 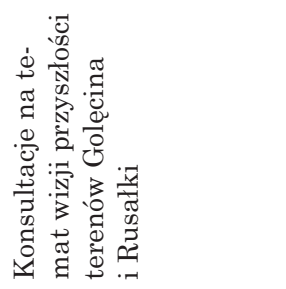 \\
\hline$\dot{+}$ & 10 & $\dot{0}$ & $\stackrel{\circ}{ }$ & $\infty$ \\
\hline
\end{tabular}


Należy zauważyć, że narzędzia e-parycypacji działają w swoistej symbiozie z mediami. Media informujacc o sondażu, wzbudzają zainteresowanie. Z tego punktu widzenia na większą medialność i zainteresowanie projektem może wpłynąć - paradoksalnie - np. błąd w kwestionariuszu bądź na stronie internetowej, ponieważ wzbudza to oburzenie prezentowane w mediach, ale przez to - także ciekawość użytkowników, którzy czujnie wychwytuja tego rodzaju potknięcia urzędników. Z kolei internetowe konsultacje sa atrakcyjne medialnie dlatego, że dziennikarze są zainteresowaniu konkretnym „wynikiem” konsultacji. Konsultacje kończące się „wynikiem” są promowane szerzej. Natomiast mniej atrakcyjne sa te konsultacje, których rezultatem są opinie niejednoznaczne, np. mające charakter równoważnych rozwiązań.

Reasumując, można stwierdzić, że narzędzia internetowe są raczej elementem szerszego procesu konsultacyjnego i dopełniają inne możliwości wypowiedzi, chyba że temat konsultacji np. skierowany jest wyłącznie do użytkowników Internetu.

Biorąc pod uwagę wskazane wcześniej funkcje partycypacji: a) lepsza legitymizację decyzji; b) pomoc w emancypacji wykluczonych grup społecznych; c) poprawa jakości podejmowanych decyzji; d) poprawa działania administracji, można uznać, że w przedstawionych powyżej procesach konsultacyjnych dadzą się stwierdzić wszystkie te funkcje. W przypadku zastosowań sondażu internetowego w Poznaniu wskazać można następujące szczegółowe cele, które sondaż miał spełniać:

- aktywizacja mieszkańców (ogółu oraz pewnych grup);

- informowanie mieszkańców;

- pozyskiwanie opinii;

- pozyskiwanie nowych pomysłów;

- hierarchizacja rozwiązań (wskazywanie priorytetów);

- wybór najlepszych projektów.

Należy zwrócić uwagę na to, że w poszczególnych przypadkach cele łącza się ze soba, choć w różnych proporcjach. Cel aktywizacyjny jest obecny zasadniczo w każdym przypadku, choć na przykład konsultowanie Planu Transportowego Aglomeracji Poznańskiej było skierowane raczej do ekspertów niż do ogółu mieszkańców i aktywizacja miała małe znaczenie.

Warto zwrócić uwagę na to, że metodologiczne ugruntowanie sondażu internetowego może być odmienne - w zależności od celu badań. Cel aktywizacyjny nie wymaga respektowania wymogów probabilistycznego doboru próby. Każda reakcja mieszkańców w takim sondażu spełnia podstawowy cel, reprezentatywność zaś nie jest konieczna. Podobnie jest w przypadku pozyskiwania pomysłów czy informowania (cel edukacyjny). Z kolei gdy chodzi o poprawę jakości podejmowanych decyzji, co wymaga dobrego rozeznania preferencji obywateli - reprezentatywność jest konieczna. Bez niej bowiem sondaż może dać wyniki „wykrzywiajace” rozkład społecznych preferencji.

Spojrzenie przez pryzmat typów sondaży internetowych wyróżnionych przez Coupera ${ }^{38}$ pozwala stwierdzić, że poznańskie konsultacje społeczne

${ }^{38}$ M. P. Couper, op. cit. 
moga zostać zaliczone do sondaży nieprobabilistycznych, a konkretnie - do sondaży opierających się na dobrowolnym uczestnictwie każdego, kto się zgłosi. Czasami były stosowne pewne znamiona kontroli próby, która polegała na podawaniu PESEL-u czy numeru legitymacji studenckiej (w przypadku Poznańskiego Budżetu Obywatelskiego), tak aby w konsultacjach brały udział jedynie osoby zameldowane lub studiujące w Poznaniu.

Można zatem stwierdzić, że sondaże internetowe spełniały głównie funkcję aktywizacyjna. Pomagaja one w emancypacji wykluczonych grup społecznych (,daja głos” mieszkańcom) oraz zapewniają lepszą legitymizację decyzji. W mniejszym stopniu przyczyniaja się do poprawy jakości podejmowanych decyzji i poprawy działania administracji. Realizowanie tych dwóch ostatnich funkcji wymagałoby większej dbałości o probabilistyczny charakter prób.

\section{PODSUMOWANIE}

Rozwój technologii informatycznych przyniósł nadzieje związane z nowymi możliwościami aktywizacji obywateli i włączania ich do procesów partycypacyjnych. Można stwierdzić, że mimo bardzo dużego rozwoju komunikacji i przepływu informacji między władzami publicznymi a obywatelami, co można obserwować w wielu krajach, nadzieje na jakościowy przełom w zarządzaniu publicznym nie spełniły się. Niemniej rozwój e-partycypacji i poszczególnych narzędzi e-partycypacji (szczególnie w USA i w Kanadzie) jest widoczny. Obok oczywistych korzyści (np. obniżenie kosztów uzyskiwania i przekazywania informacji), rodzi to także obawy, czy nie pociaga to za sobą utrwalenia istniejących nierówności i czy nie dochodzi do powstawania nowych. W przedstawionej powyżej analizie różnego zastosowania sondażu internetowego do prowadzenia konsultacji w Poznaniu zwrócono uwagę na to, czy zastosowanie tego narzędzia nie powoduje systematycznego „wykrzywienia” uzyskiwanych wyników. Gwałtowny wzrost popularności sondaży internetowych, który można obserwować, wynika z tego, że jest to metoda tania. Jednocześnie jednak może ona prowadzić do przekłamań. W szczególności niebezpieczeństwo to dotyczy zastosowań sondażu internetowego jako narzędzia partycypacyjnego. Reprezentatywność jest kluczowa, gdy sondaż ma przynieść rzeczową informację (np. na temat rozkładu preferencji), funkcją zaś jest uzyskanie najwyższej jakości decyzji. Jednocześnie, gdyby chodziło o funkcję aktywizacji i pomocy w emancypacji wykluczonych grup społecznych, reprezentatywność nie jest najważniejsza. Może ona mieć pewne znaczenie, lecz w niektórych sytuacjach może mieć znaczenie marginalne.

W rzeczy samej zastosowanie sondaży internetowych w Poznaniu miało de facto przede wszystkim funkcję aktywizacyjna. Trzeba zauważyć, że w tym zakresie doświadczenia są pozytywne. W sondażach uczestniczy często kilka tysięcy mieszkańców. Zainteresowanie w niektórych przypadkach było jakościowo większe, niż spodziewali się organizatorzy. Jednocześnie niebezpieczeństwo związane $\mathrm{z}$ wytwarzaniem wykluczenia cyfrowego jest minimalizowane przez to, że sondaże internetowe, czy w ogóle internetowe narzędzia konsul- 
tacji społecznych stosowane w Poznaniu, praktycznie nigdy nie były jedynym narzędziem wyrażania opinii czy oddania głosu (poza przypadkiem konsultacji na temat wyboru wtórnika rejestracyjnego).

Zastosowania sondażu internetowego wskazują na konieczność dostosowania narzędzia do celu badania oraz spodziewanego zainteresowania. W przypadku kilkuset lub tysięcy opinii/głosów potrzebna jest analiza ilościowa, co należy uwzględnić na etapie przygotowań. Z drugiej strony, jeśli liczba spodziewanych odpowiedzi jest mała, wymaga to użycia adekwatnego narzędzia.

Jeśli sondaż internetowy ma pełnić funkcje wykraczające poza aktywizację, legitymizację decyzji i generowanie rozwiązań i jeśli ma dawać obraz rozkładów preferencji, by pomóc w podejmowaniu lepszych decyzji, niezbędna jest dbałość o metodologię badań i taki dobór próby, by możliwe było oszacowanie błędów.

dr hab. Piotr Matczak

Uniwersytet im. Adama Mickiewicza w Poznaniu matczak@amu.edu.pl

mgr Krzysztof Maczka

Uniwersytet im. Adama Mickiewicza w Poznaniu

krzysztof.maczka@amu.edu.pl

dr Maciej Milewicz

Uniwersytet im. Adama Mickiewicza w Poznaniu

maciej_milewicz@um.poznan.pl

\section{E-PARTICIPATION: \\ APPLICATION OF A WEB SURVEY AS A PARTICIPATORY TOOL}

Sum mary

The development of information and communication technologies over the last 25 years has changed the context and practice of participation. There emerged the concept of e-participation, meaning the interaction between the sphere of civil society and the formal sphere of politics and administration, through information technology. The paper presents the functions of e-participation, the tools used and the criticism raised at this method of engaging citizens. Further, e-participation practice in Poland is introduced with a detailed case of web surveys in Poznan which are used as a consultation tool. Finally, the conclusions are offered, based on an analysis of the use of web surveys as a tool of e-participation. The surveys carried out in Poznań can be classified as based on non-probabilistic sampling. They rely on the voluntary participation of respondents who come forward. Internet surveys meet the mostly activation. Thus, they empowered marginalized social groups ('give voice' to inhabitants) gave greater legitimacy to decisions. To a lesser extent, this tool contributed to improving the quality of decision making and to an improvement in the workings of the administration. The implementation of the latter two functions would require greater attention to the probabilistic characteristic of the sampling. 